\title{
Outcomes of allogeneic hematopoietic stem cell transplantation in children and adults with prior invasive fungal diseases
}

\author{
Marina O. Popova ${ }^{1}$, Alisa G. Volkova ${ }^{1}$, Inna V. Markova ${ }^{1}$, Oksana V. Ayzsilnieks ${ }^{1}$, Yulia A. Rogacheva ${ }^{1}$, \\ Anastasia S. Frolova ${ }^{1}$, Aleksandr N. Shvetcov ${ }^{1}$, Ilya Y. Nikolaev ${ }^{1}$, Svetlana M. Ignatyeva ${ }^{2}$, Tatyana S. Bogomolova ${ }^{2}$, \\ Asmic G. Gevorgian ${ }^{1}$, Olesya V. Paina ${ }^{1}$, Tatiana A. Bykova ${ }^{1}$, Elena I. Darskaya ${ }^{1}$, Maria V. Vladovskaya ${ }^{1}$, \\ Ivan S. Moiseev ${ }^{1}$, Ludmila S. Zubarovskaya ${ }^{1}$, Nikolay N. Klimko ${ }^{1,2}$, Boris V. Afanasyev ${ }^{1}$ \\ ${ }^{1}$ Raisa Gorbacheva Memorial Research Institute of Pediatric Oncology, Hematology and Transplantation, Chair of Hematology, \\ Transfusiology and Transplantology, Pavlov First Saint Petersburg State Medical University, St. Petersburg, Russia \\ ${ }^{2}$ Dept. of Clinical Mycology, I. Mechnikov North-Western State Medical University, St. Petersburg, Russia
}

Marina O. Popova, PhD (Medicine), Clinical Hematologist, BMT Department for adults, Raisa Gorbacheva Memorial Research Institute of Pediatric Oncology, Hematology and Transplantation, Associate Professor, Pavlov First Saint Petersburg State Medical University, L. Tolstoy St 6-8, 197022, St. Petersburg, Russia
Phone: +7 (911) 7113977

E-mail: marina.popova.spb@gmail.com

Citation: Popova MO, Volkova AG, Markova IV et al. Outcomes of allogeneic hematopoietic stem cell transplantation in children and adults with prior invasive fungal diseases. Cell Ther Transplant 2019; 8(2): 17-25.

\section{Summary}

Invasive fungal diseases (IFD) are a major cause of morbidity and mortality in hematological patients, but prognosis of IFD has improved recently, due to introduction of new antifungals and efficient diagnostic procedures. Number of patients with IFD who are candidates for allogeneic hematopoietic stem cell transplant (allo-HSCT) increased. However, publications on the field are limited and there are no data on results of pediatric allo-HSCT patients with prior IFD. This study focuses on the outcomes of allo-HSCT in children and adults with prior IFD.

\section{Patients and methods}

In a prospective study, 504 allo-HSCT recipients were included from Jan 2013 to Jul 2016. The median age was 24 y.o. [ 2 months to 76 years] including 164 children ( $<18$ yo) and 340 adults. The cohort included 52\% male patients. Most patients (74.6\%) were diagnosed with high-risk acute leukemia. Allo-HSCT from HLAmatched unrelated donors (MUD) was performed in $58.5 \%$, from matched related donors (MRD), 22.5\%; haploidentical HSCT was performed in $19 \%$ of patients, predominantly with RIC (67\%). EORTC/MSG 2008 criteria for diagnosis and response to therapy were used.
In the patients with pre-transplant lung lesions detected by CT scan, bronchoscopy with BAL was used. "Active IFD” means IFD diagnosed just before HSCT.

\section{Results}

Incidence of IFD before allo-HSCT was $15 \%(n=76)$. According to EORTS/MSG 2008 criteria, $90.8 \%$ of patients had probable and $9.2 \%$ presented with proven IFD. Etiology of IFD prior to HSCT was as follows: invasive aspergillosis (IA), 75\%; invasive candidiasis (IC), $13 \%$; mucormycosis (Mu), 4\%; Pneumocystis pneumoniae (PCP), $1.3 \%$, and combination of IA with $\mathrm{Mu}(2$ cases), IC $(n=1), \operatorname{PCP}(n=1)$. The main sites of infection were lungs (95\%), other localizations were predominantly combined with lung involvement: sinuses (9\%), spleen (6\%), liver (6\%), and soft tissues (3\%). Antifungal therapy before allo-HSCT was used in $75 \%$ patients with median duration of 2 months. Complete response to antifungal therapy was observed in $38.2 \%$ of the cases, partial response or stabilization was achieved in $35.5 \%$, and "active IFD" was detected in $26.3 \%$ of the patients. After allo-HSCT, all the patients received antifungal therapy or secondary prophylaxis according to the IFD etiology. Cumulative incidence of relapse or progression of IFD after allo-HSCT was observed in $14.5 \%$. Active underlying disease (hematology malignancy) at the moment 
of HSCT was the only risk factor for relapse or progression of IFD after allo-HSCT (11.5\% vs $21.1 \%, \mathrm{p}=0,03)$. We detected no significant differences in the cumulative incidence of acute, chronic GVHD and relapse in the study group as compared to the patients without history of IFD. 3-year overall survival (OS) after allo-HSCT was $67.5 \%$. The impact of prior IFD on overall survival in allo-HSCT recipients was not statistically significant for the entire group $(60.5 \%$ vs $68.7 \%, \mathrm{p}=0.1)$, and, separately, for children $(50.0 \%$ vs $57.4 \%, \mathrm{p}=0,3)$ and adults (63.3\% vs $74.6 \%, \mathrm{p}=0.09$ ). The worst outcome was observed in the patients with "active IFD" and active underlying disease at the moment of HSCT (3-year OS was $20 \%, p<0.001$ compared to patients without history of IFD). However, in the patients with "active IFD" and remission of underlying disease, OS value was similar to survival rate of patients without history of IFD $(80 \% v s$ $68.7 \%, \mathrm{p}=0.2$ ).

\section{Conclusion}

Incidence of IFD before allo-HSCT was 15\%. Cumulative incidence of relapse or progression of IFD after allo-HSCT was $14.5 \%$. Prior IFD had no significant impact on transplant-related complications and overall survival in children and adults undergoing allo-HSCT. Active underlying disease at the moment of HSCT was the only risk factor for relapse or progression of IFD and impaired outcome of allo-HSCT.

\section{Keywords}

Invasive fungal disease, pre-existing IFD, allogeneic hematopoietic stem cell transplantation, children and adults, clinical outcomes.

\section{Introduction}

Allogeneic hematopoietic stem cell transplantation (alloHSCT) is the most effective treatment method for lymphoid, haematopoietic and related tissue malignancies as well as non-malignant disorders. In 2017, 18.281 number of allo-HSCT were performed in Europe and associated countries reported by 683 centers in 50 countries, with acute leukemia being the main indication [1]. The approachability and outcome of allo-HSCT are steadily improving due to wide application of reduced-intensity conditioning (RIC), new methods of graft-versus-host disease (GvHD) prophylaxis, haploidentical transplantation, and introduction of novel molecules and drugs for bridge therapy before alloHSCT, along with prevention and treatment of relapses after allo-HSCT both in adults and pediatric patients [2-8] Invasive fungal disease (IFD) is a common infectious complication during remission-induction and/or consolidation chemotherapy for aggressive hematologic malignancies. The patients with acute leukemia and high-risk myelodysplastic syndrome are also at high risk for IFD [9-10]. Some patients with relapsed/refractory lymphoma could be, under some circumstances, also attributed to the high-risk group [11]. Introducing new antifungal drugs and diagnostic procedures has improved prognosis of IFD in hematological disorders. Many of these patients will subsequently be referred for allo-HSCT because of high-risk hematological malignances. The number of patients with IFD who are candidates for allo-HSCT has been also increased, and the problems related to the transplant procedure are pressing now. An observational study of the Transplant Associated Infection Surveillance Network (TRANSNET) suggests that the post-transplant IFD remains problematic, with cumulative incidence rates varying between 5.8 and $7.7 \%$ [12]. The role of IFD revealed prior to allo-HSCT is still a subject of controversy. Historically, IFD has been a major barrier for allo-HSCT. Previous studies have shown that invasive aspergillosis (IA) may have a significant role in clinical outcome of allo-HSCT [13-15]. Fukuda et al. have summarized the 10-year expe- rience of Fred Hutchinson Cancer Research Center, having shown that the post-transplant IA occurred in 13 of 45 patients with a pre-transplant IA history (29\%) [16]. Nine infectious events were considered to be recurrent by anatomic site and timing. Compared with all other patients who received allo-HSCT over the same period, the patients with IA history had lower 1-year overall survival rate $(56 \%$ versus $77 \% ; \mathrm{P}=0.0001$ ), and higher transplant-related mortality ( $38 \%$ versus $21 \% ; \mathrm{P}=0.0001$ ) by 100 days after HSCT, associated mainly with IA and other pulmonary complications. The CIBMTR data also confirm that 5 -year overall survival was 30\% (95\% Confidence interval (CI): 26-34\%) at 5 years in patients with pre-transplant IFD versus $45 \%$ (95\% CI: 44$46 \%)$ in control population ( $\mathrm{p}<0.0001)$. The lower overall survival seems to be a composite result of higher relapse rates and higher non-relapse mortality in the patients with pre-existing IFD [17].

Historically, pre-transplant IFD was considered a relative contraindication to HSCT. However, recent studies have demonstrated a controversial point, e.g., a single-center study on behalf of CIC 725 suggested that IA prior to allo-HSCT did not impair the outcome of transplantation procedure with effective diagnosis and secondary prophylaxis of IFD, as reported at the $41^{\text {st }}$ Annual EBMT Meeting and $57^{\text {th }}$ Annual ASH Meeting in $2015[18,19]$. A retrospective EBMT analysis by the Infectious Diseases and Acute Leukemia Working Parties concerning influence of pre-existing invasive aspergillosis upon allo-HSCT outcome in acute leukemia patients (published online in October 2015 in Bone Marrow Transplantation) confirm our data that, in general, a history of IA should not be a contraindication when considering allo-HSCT in acute leukemia patients [20]. Penack O. et al. found only a trend toward lower overall survival $(\mathrm{P}=0.078$, hazard ratio (HR) [95\% confidence interval (CI): 1.16 (0.98, 1.36)], and higher non-relapse mortality [ $\mathrm{P}=0.150, \mathrm{HR}(95 \%$ CI): $1.19(0.94,1.50)]$ in allo-HSCT recipients with pre-existing IA [20]. So far, there are no available data on clinical effects of other then IA pre-existing IFD and in pediatric allo-HSCT recipients. 
The aim of this study was to estimate impact of prior proven or probable invasive fungal diseases on clinical outcome of allo-HSCT in children and adults.

\section{Patients and methods}

We have conducted a prospective single center study, where 504 allo-HSCT recipients were included from Jan 2013 to Jul 2016, with median follow-up time of 20 months and median age of 24 y.o. [ 2 months to 76 years]. The study cohort included 164 children ( $<18$ yo), 340 adults, 52\% were males. Most patients had high-risk acute leukemia (74.6\%). AlloHSCT from MUD was performed in 58.5\%; MRD, 22.5\%; haplo-HSCT, 19\%. Reduced-intensity conditioning regimens (RIC) were predominant (67\% of the cases). General characteristics of patients, donors and transplants are outlined in Tables 1,2. The patients with lymphoid, haematopoietic and related tissue malignancies as well as non-malignant disorders received primary chemotherapy and other treatment in various regions of Russian Federation, from where most of the data including history of prior IFD were collected. All the patients with CT-detectable lesions at the time of trans-

\section{Table 1. Clinical and demographic characteristics of the patients}

\begin{tabular}{|c|c|}
\hline Patients characteristics & $\mathrm{n}=504$ \\
\hline Age, median (range) & $24[2 \mathrm{mo}-76 \mathrm{y}]$ \\
\hline$\leq 18$ & 177 (35\%) \\
\hline $19-60$ & 312 (62\%) \\
\hline$\geq 60$ & $15(3 \%)$ \\
\hline Sex Males & $262(52 \%)$ \\
\hline Acute leukemia & 376 (74.5\%) \\
\hline AML/ALL & 213/163 \\
\hline CR 1-2 & $262(70 \%)$ \\
\hline Prim refr/no CR & 114 (30\%) \\
\hline Myeloproliferative disease & $59(12 \%)$ \\
\hline $\mathrm{CR}$ & $15(25 \%)$ \\
\hline no CR & 44 (75\%) \\
\hline Lymphoproliferative disease & $31(6 \%)$ \\
\hline CR & $17(55 \%)$ \\
\hline Prim refr/no CR & $14(45 \%)$ \\
\hline Non-malignant disease & $38(7.5 \%)$ \\
\hline \multirow{3}{*}{$\begin{array}{l}\text { Status of the disease } \\
\text { Complete remission } \\
\text { No complete remission/primary } \\
\text { refractoriness }\end{array}$} & \\
\hline & $299(60 \%)$ \\
\hline & 205 (40\%) \\
\hline
\end{tabular}

Abbreviations: $A M L$, acute myeloid leukemia; ALL, acute lymphoblastic leukemia; CR, complete remission; CI, calcineurin inhibitors; Mtx, methotrexate; MMF, mycophenolate mofetil; ATG, Anti-thymocyte globulin; PTCY, posttransplant cyclophosphamide.

plantation were subjected to diagnostic bronchoscopy with bronchoalveolar lavage (BAL) microscopy, microbiological cultures and galactomannan (GM) test. EORTC/MSG 2008 criteria were used for the diagnosis of proven and probable IFD as well as to evaluate response to therapy. An "active" invasive fungal disease means IFD diagnosed just before allo-HSCT during examination at $<1$ month before starting the conditioning regimen.

The following primary endpoints were used: incidence of pre-existing IFD, incidence of relapse or progression of IFD after allo-HSCT, and overall survival (OS). The secondary endpoints included influence of pre-existing IFD on other outcomes of allo-HSCT, i.e., acute GvHD, chronic GvHD, relapse of underlying disease.

Overall survival was estimated using the Kaplan-Meier method. Mortality due to any cause was considered as a distinct event. Patients alive at the end of the follow-up were censored at this date. Patients with pre-existing IFD and without pre-existing IFD will be compared by the log-rank test. A Cox regression was applied, in order to compare the outcomes the study groups.

Table 2. Characteristics of hematopoietic transplants

\begin{tabular}{|c|c|}
\hline Transplant characteristics & $n=504$ \\
\hline $\begin{array}{l}\text { Donor type } \\
\text { Matched related } \\
\text { Mismatched related } \\
\text { Matched unrelated } \\
\text { Mismatched unrelated }\end{array}$ & $\begin{array}{l}113(22.5 \%) \\
96(19 \%) \\
194(38.5 \%) \\
101(20 \%)\end{array}$ \\
\hline $\begin{array}{l}\text { Conditioning regimen } \\
\text { Myeloablative } \\
\text { Reduced-intensity }\end{array}$ & $\begin{array}{l}166(33 \%) \\
338(67 \%)\end{array}$ \\
\hline $\begin{array}{l}\text { Source of the transplant } \\
\text { Bone marrow } \\
\text { Mobilized peripheral blood stem cells } \\
\text { Both }\end{array}$ & $\begin{array}{l}253(50 \%) \\
241(48 \%) \\
10(2 \%)\end{array}$ \\
\hline Dose of CD34+ cells, $10^{6} / \mathrm{kg}$, mean $\pm S D$ & $4.9 \pm 1.8$ \\
\hline $\begin{array}{l}\text { GvHD prophylaxis } \\
\mathrm{Cl}+\mathrm{Mtx} / \mathrm{MMF}+/-\mathrm{ATG} \\
\mathrm{Cl}+\mathrm{MMF}+\mathrm{PTCY} / \text { mono PTCY }\end{array}$ & $\begin{array}{l}69(14 \%) \\
435(86 \%)\end{array}$ \\
\hline $\begin{array}{l}\text { Antifungal prophylaxis } \\
\text { Primary: fluconazole } \\
\text { Secondary: voriconazole }\end{array}$ & $\begin{array}{l}262(61 \%) \\
57 \text { (75\%) }\end{array}$ \\
\hline
\end{tabular}




\section{Results}

The overall incidence of IFD before allo-HSCT was $15 \%$ ( $\mathrm{n}=76)$. According to EORTS/MSG 2008 criteria 90.8\% of patients had probable IFD, and 9.2\% exhibited proven fungal invasion. Patients with lymphoma, as well as those with acute myeloid leukemia had a higher rate of pre-existing IFD at the time of allo-HSCT (Fig. 1).

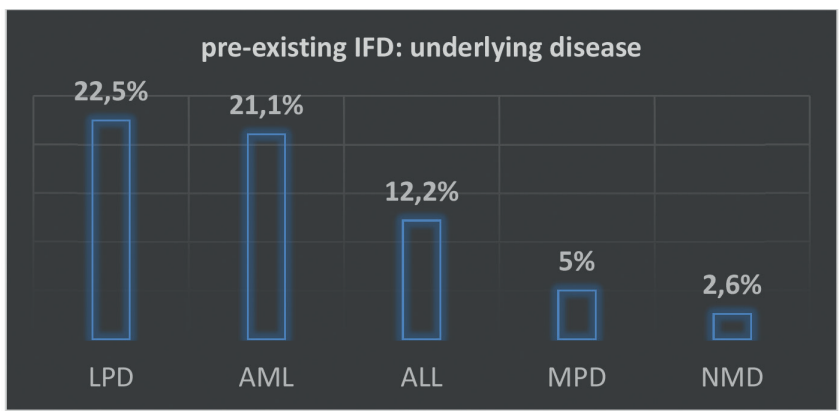

Figure 1. Primary underlying diseases in the patients with pre-existing IFD

Abbreviations: $L P D$, lymphoproliferative disease; $A M L$, acute myeloid leukemia; ALL, acute lymphoblastic leukemia; MPD, myeloproliferative disease; NMD, non-malignant disease.

The pathogens detected in IFD prior to allo-HSCT were as follows: invasive aspergillosis, $75 \%$; invasive candidiasis (IC), 13\%; mucormycosis (Mu), 4\%; Pneumocystis pneumoniae (PCP), 1,3\%; combination of IA with $\mathrm{Mu}$ was found in 2 patients, IC in one case, and PCP, in one another case (Fig. 2). The main sites of infection were lungs (95\%), other affected sites were predominantly combined with lung lesions, i.e., maxillary or frontal sinuses, $9 \%$; spleen, $6 \%$; liver, $6 \%$, and soft tissues, $3 \%$ (Fig. 3).

\section{pre-existing IFD: etiology}

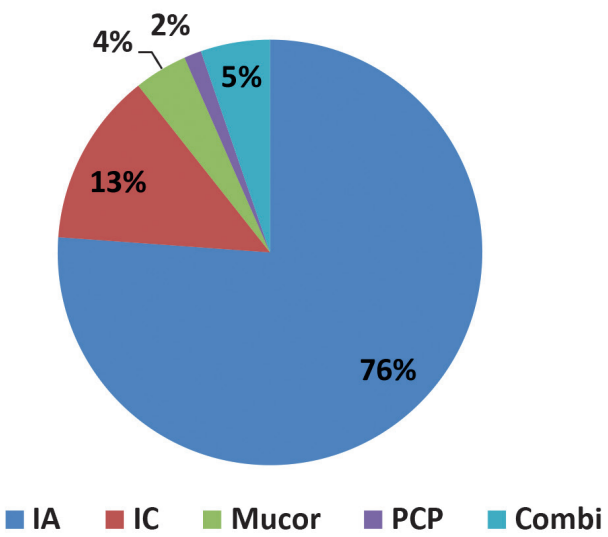

Figure 2. Causative pathogens in pre-existing IFD cases

Abbreviations: IA, invasive aspergillosis; IC, invasive candidiasis; Mu, mucormycosis; PCP, Pneumocystis pneumoniae; Combi, mixed fungal invasion.

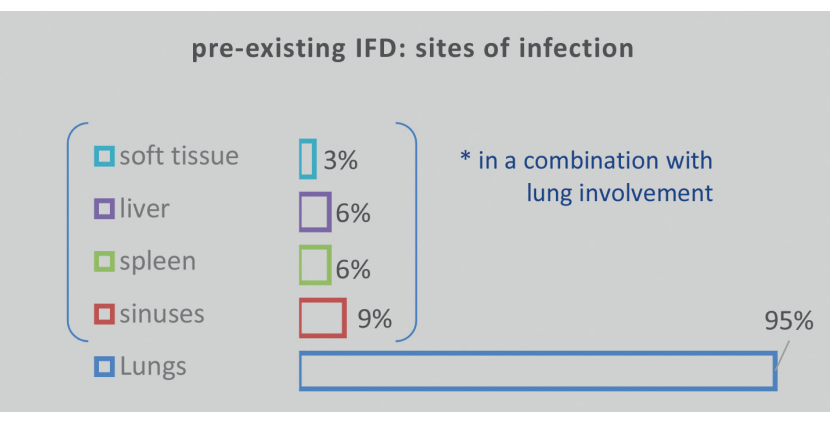

Figure 3. Sites of infections in patients with pre-existing IFD

The median time from IFD to allo-HSCT was 86 days [ 1 day to 4.5 years]. Antifungal therapy before allo-HSCT was administered in $75 \%$ patients. The median duration of antifungal therapy before allo-HSCT was 65 days [ 1 day-11 months]. Complete response to antifungal treatment was achieved in $38.2 \%$ patients, partial response or stabilization were observed in $35.5 \%$, and $26.3 \%$ patients had "active IFD". After allo-HSCT, all the patients received antifungal therapy or secondary prophylaxis according to the IFD etiology, with median duration of clinical effect for 78 [21-217] days, and median therapy length for 166 [32 to 394 days].

Cumulative incidence of relapse or progression of IFD after allo-HSCT was $14.5 \%$ (Fig. 4). Active underlying disease at the moment of HSCT was the only risk factor for relapse or progression of IFD after allo-HSCT ( $11.5 \%$ vs $21.1 \%, \mathrm{p}=0.03)$ (Fig. 5). We detected no significant differences in cumulative incidence of acute or chronic GVHD, and relapse rates in the study group as compared to the patients without history of IFD. Patients and HSCT characteristics, CMV reactivation, graft hypofunction did not show any significant association with incidence of relapse, or progression of IFD after allo-HSCT. The characteristics related to pre-existing IFD (status of IFD at the HSCT, time from IFD to HSCT, duration of antifungal therapy before HSCT) also had no impact on probability of relapse or progression of IFD after allo-HSCT.

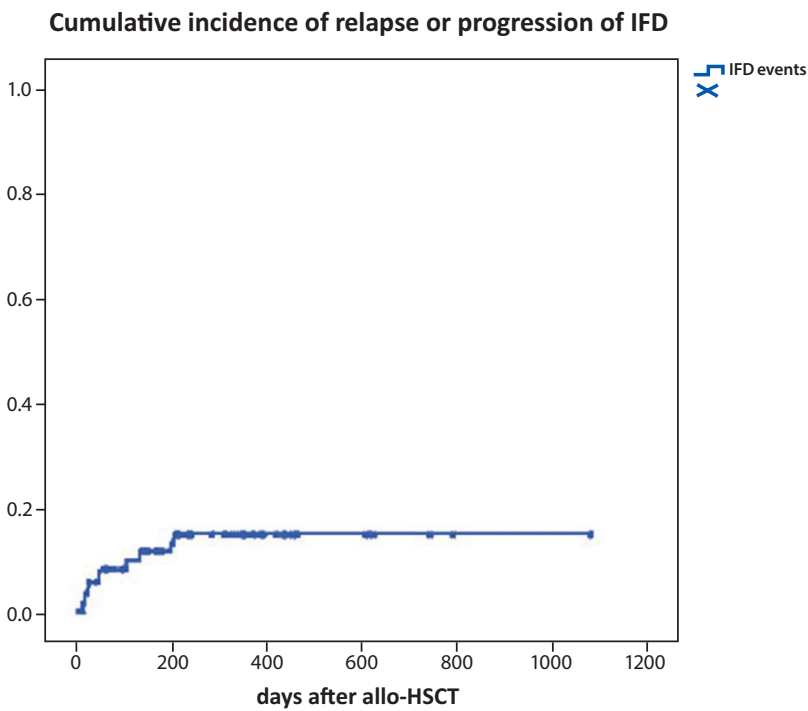

Figure 4. Cumulative incidence of relapse or progression of IFD after allo-HSCT (ordinate). Abscissa, days after HSCT 
Cumulative incidence of relapse or progression of IFD

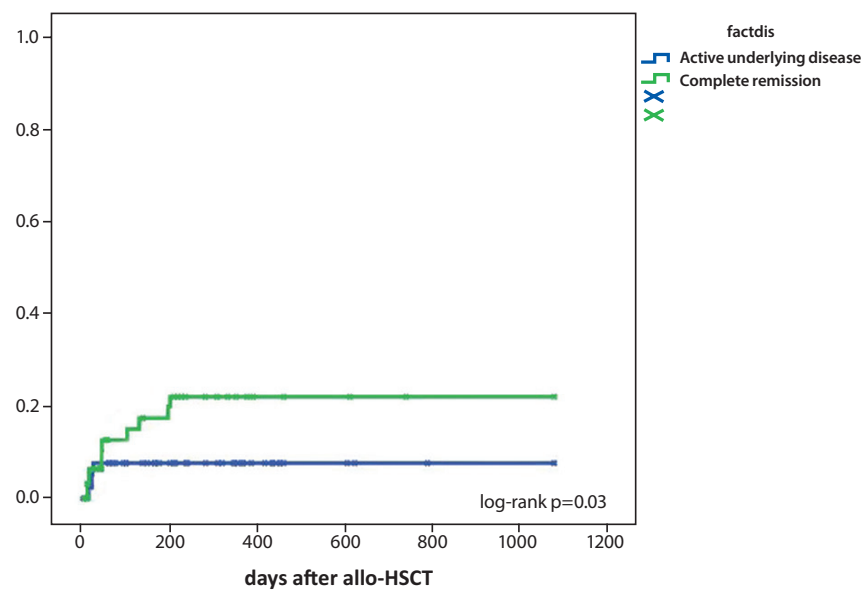

Figure 5. Cumulative incidence of relapse or progression of IFD after allo-HSCT depending on the underlying disease status at the moment of allo-HSCT (ordinate). Abscissa, days after HSCT

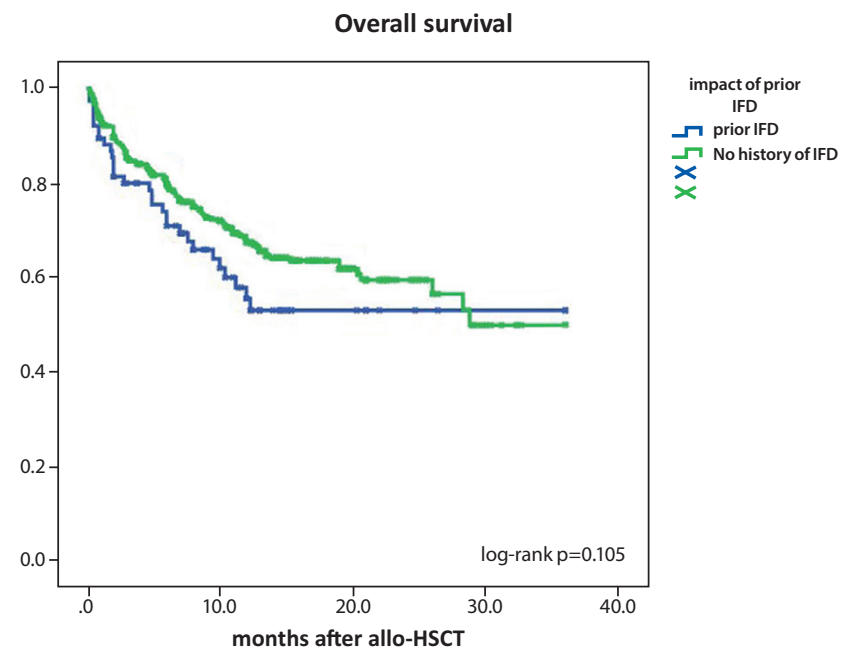

Figure 6. Three-year overall survival after allo-HSCT in the patients with history of prior IFD as compared to patients without history of IFD (ordinate). Abscissa, months after HSCT
Three-year OS after allo-HSCT was $67.5 \%$. The impact of prior IFD upon overall survival in allo-HSCT recipients was not statistically significant in the entire group $(60.5 \%$ vs $68.7 \%, \mathrm{p}=0.1$ ) (Fig. 6). Similar results were obtained for the separate groups of children $(50.0 \%$ vs $57.4 \%, \mathrm{p}=0.3)$, and adults $(63.3 \%$ vs $74.6 \%, \mathrm{p}=0.09)$. The main outcomes of alloHSCT are presented in Table 3.

The worst outcome was observed in patients with "active IFD" and active underlying disease at the moment of alloHSCT (3-year OS - 20\%, p<0.001; HR (95\% CI): 5.81 (2.81 11.87)). However, OS values in patients with "active IFD" and remission of underlying disease were similar to survival rate of patients without history of IFD ( $80 \%$ vs $68.7 \%, \mathrm{p}=0.2$, $\mathrm{p}=0.57$, HR [(95\% CI): $0.67(0.16-2.71)]$ (Fig. 7).

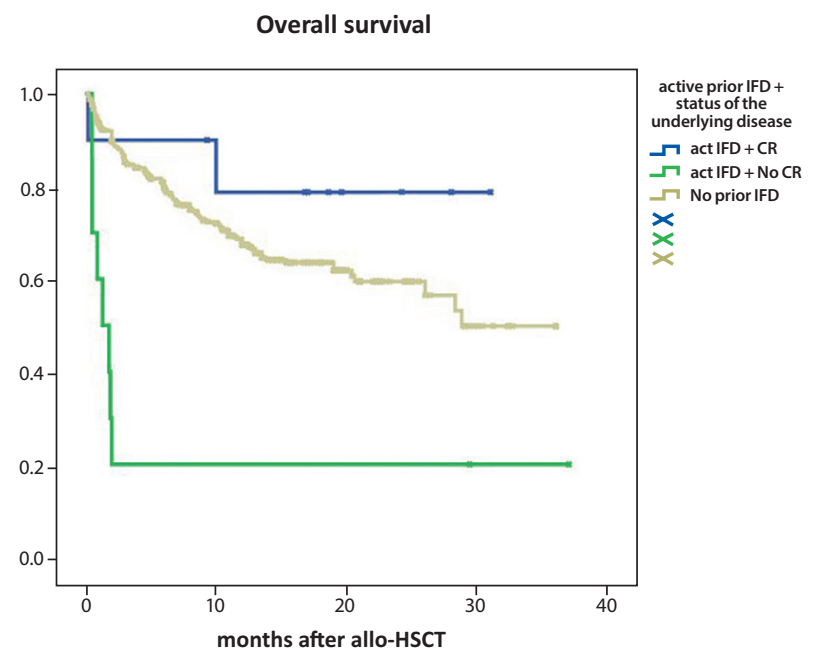

Figure 7. Three-year overall survival after allo-HSCT in the patients with "active IFD" (depending on status of underlying disease at the moment of allo-HSCT) as compared to patients without history of IFD (ordinate). Abscissa, months after HSCT

Comments: blue line is survival curve for the group of patients with "active IFD" and remission of underlying disease; green line is survival curve for the group of patients with "active IFD" and active underlying disease at the moment of allo-HSCT; the yellow line is survival curve for the patients without history of IFD.

Table 3. The main outcomes of allo-HSCT in patients with history of prior IFD as compared to patients without history of IFD

\begin{tabular}{|l|l|l|l|l|l|}
\hline \multirow{2}{*}{ Outcomes of allo-HSCT } & \multicolumn{2}{|l|}{ Prior IFD } & \multirow{2}{*}{$\mathbf{p}$} & HR & (95\% Cl) \\
\cline { 2 - 6 } & yes & no & & & \\
\hline 3y OS (adult + children) & $60.5 \%$ & $68.7 \%$ & 0.10 & 1.38 & $0.93-2.05$ \\
\hline 3y OS (adult) & $63.3 \%$ & $74.6 \%$ & 0.09 & 1.50 & $0.93-2.42$ \\
\hline 3y OS (children) & $50.0 \%$ & $57.4 \%$ & 0.32 & 1.44 & $0.69-3.02$ \\
\hline Incidence of acute GvHD grade II-IV & $18.1 \%$ & $19.8 \%$ & 0.28 & 0.91 & $0.69-1.20$ \\
\hline Incidence of chronic GvHD & $27.8 \%$ & $32.9 \%$ & 0.25 & 0.82 & $0.74-1.07$ \\
\hline Relapse of underlying disease & $32.6 \%$ & $30.8 \%$ & 0.31 & 1.21 & $0.89-1.59$ \\
\hline
\end{tabular}




\section{Discussion}

In the present study, we analyzed large data set of patients with different hematological malignancies and non-malignant disorders undergoing allo-HSCT between 2013 and 2016 in a single BMT center (CIC 725). We would highlight the real-life character of study. The entire cohort of alloHSCT recipients was included in the observation period without exception of any patients, regardless of underlying disease or status at the moment of allo-HSCT. Also we would emphasize the participation of pediatric cohort that was presented by 164 children.

In our population of allo-HSCT recipients, $15 \%$ had proven and probable invasive fungal disease before transplantation. Moreover, most of them ( $>60 \%$ ) had signs of the infection at the moment of allo-HSCT. We believe that there are several factors that could contribute to our results. Out BMT team has wide diagnostic opportunities and an active diagnostic strategy related to infections, and is able to perform the on-place assessment of infectious state of the patient before allo-HSCT, because of lacking necessary diagnostic procedures in most regions where the patients were initially treated. Due to successful implementation of such strategy, we are more often prone for active treatment and avoiding delays with allo-HSCT. An unexpected result for us is the fact that a quarter of patients with lymphomas had IFD before allo-HSCT. This result may be due to high pre-treatment burden in these patients, most of them were patients with Hodgkin lymphoma who underwent more than 6 lines of chemotherapy before allo-HSCT.

Our study has also shown that the cumulative incidence of relapse or progression of invasive fungal disease after allo-HSCT was $14.5 \%$. The only risk factor for relapse or progression of IFD was lack of complete remission of the underlying disease at the moment of HSCT. That result corresponded to the earlier reported data [16], but we didn't find any additional risk factors associated with bone marrow transplant procedure or antifungal treatment before alloHSCT.

In the present study, we demonstrated that invasive fungal disease prior to the allo-HSCT did not impact on outcome of this treatment in children and adults. We suggest that there are several features that may have endow to obtained results.

Firstly, our study included allo-HSCT recipients who have been transplanted over recent years, in comparison with published studies [13-16, 20]. An overall better supportive care management was applied over last years, thus improving, specifically the outcome of allo-HSCT in patients with infectious complications including IFD. We believe that active diagnostic strategy and wide implementation of modern medications for secondary prophylaxis in our center played a role in improving the outcome of allo-HSCT in the patients with pre-existing IFD. It has been shown in several trials that secondary antifungal prophylaxis with voriconazole leads to considerably lower IA relapse rates as compared with those reported in historical controls, since Aspergillus spp. is a prevailing pathogen in pre-transplant IFD in our study [21-23].

Secondly, this study demonstrated the central role of the underlying disease status upon outcome of the allo-HSCT, and influence on the course of the infectious complications after HSCT, IFD in our case. Active underlying disease at the moment of HSCT was the only risk factor for relapse or progression of IFD and impaired outcome of allo-HSCT. This hypothesis is supported by publications from a French-Belgium study group, demonstrating that the outcome of severe infectious complications in patients with hematological malignancies has been considerably improved during the last decade and is mostly determined by the status of the underlying disease [24-25].

Thirdly, our study has limitations due to relatively small study cohort from a single center data. That is why the result may be not accurate enough to evaluate the effect of IFD upon allo- HSCT outcome. At the same time, it reflects the situation during certain time which significantly affects the results obtained. Therefore, we cannot exclude the possibility that pre-existing IFD has a higher adverse impact on alloHSCT outcome than our data may suggest.

In conclusion, we found out no significant impact upon important allo-HSCT transplant outcomes, such as survival, GvHD and relapse. Our data suggest that a history of IFD should not be considered a contraindication for allo-HSCT. We are currently continuous an observational prospective study to be able to more precisely investigate the impact of IFD on allo-HSCT.

\section{Acknowledgments}

The authors would like to acknowledge all medical staff at our University' BMT clinic CIC725. Special thanks to our ICU department, our transplant nurses' team for their particular care of our patients. Many thanks to specialists of Department of Clinical Microbiology at the First Pavlov State Medical University of Saint-Petersburg, especially to dr. Olga Pinegina and Chief of the Department, and special gratitude to patients and their relatives.

\section{Conflict of interest}

No conflict of interests is declared.

\section{References}

1. Passweg JR, Baldomero H, Basak GW, Chabannon C, Corbacioglu S, Duarte R, Kuball J, Lankester A, Montoto S, de Latour RP, Snowden JA, Styczynski J, Yakoub-Agha I, Arat M, Mohty M, Kröger N; European Society for Blood and Marrow Transplantation (EBMT). The EBMT activity survey report 2017: a focus on allogeneic HCT for nonmalignant indications and on the use of non-HCT cell therapies. Bone Marrow Transplant 2019, Feb 6. doi: 10.1038/s41409019-0465-9.

2. Afanasyev BV, Zubarovskaya LS, Semenova EV, Ivanova NE, Alyanskiy AL, Morozova EV, Mikhailova NB, Darskaya EI, Estrina MA, Golovacheva AA, Babenko EV, Bondarenko SN, Ganapiev AA, Bogomolny MP. The experience in non-relative allogenic transplantation of stem hemopoietic cells in the clinic of bone marrow transplantation at I. P. Pavlov St. Petersburg Medical Academy. Terapevticheskii Arkhiv 2007, 79 (7):36-43 (In Russian). 
3. Bondarenko SN, Moiseev IS, Slesarchuk OA, Darskaya EI, Ekushev KA, Smirnova AG, Alyanskiy AL, Gindina TL, Babenko EV, Kuzmich EV, Semenova EV, Kulagin $\mathrm{AD}$, Zubarovskaya LS, Afanasyev BV. Allogeneic hematopoietic stem cell transplantation in children and adults with acute lymphoblastic leukemia. Cell Ther Transplant. 2016, 5 (2):12-20.

4. Afanasyev BV, Zubarovskaya LS, Moiseev IS. Allogeneic hematopoietic stem cell transplantation in children: now, problems and prospects. Russian Journal of Children Hematology and Oncology. 2015, 2: 28-42 (In Russian).

5. Baron F, Labopin M, Peniket A, Jindra P, Afanasyev B, Sanz M.A, Deconinck E, Nagler A, Mohty M. Reduced-intensity conditioning with fludarabine and busulfan versus fludarabine and melphalan for patients with acute myeloid leukemia: A report from the Acute Leukemia Working Party of the European Group for Blood and Marrow Transplantation. Cancer 2015; 121(7): 1048-1055.

6. Moiseev IS, Pirogova OV, Babenko EV, Gindina TL, Darskaya EI, Morozova EV, Bondarenko SN, Afanasyev BV. Single-agent post-transplantation cyclophosphamide versus calcineurin-based graft-versus-host disease prophylaxis in matched related bone marrow transplantation. Cell Ther Transplant. 2017; 6 (4): 52-59.

7. Bykova TA, Borovkova AS, Osipova AA, Ovechkina VN, Sheveleva PV, Nadzhafava KU, Yager VU, Paina OV, Kozhokar PV, Alyanskyi AL, Kulagin AD, Semenova EV, Smirnov BI, Zubarovskaya LS, Afanasyev BV. Acute GvHD prophylaxis with posttransplant cyclophosphamide after hematopoietic stem cell transplantation (HSCT) for non-malignant disorders. Pediatric Hematology/Oncology and Immunopathology 2018, 17 (2), pp. 51-58 (In Russian).

8. Moiseev IS, Darskaya EI, Bykova TA, Morozova EV, Alyanskiy AL, Babenko EV, Bondarenko SN, Markova IV, Afanasyev BV. Different risk factors of acute and chronic graft-versus-host disease with conventional prophylaxis and posttransplantation cyclophosphamide in matched related and unrelated donor transplantation. Cell Ther Transplant. 2018; 7 (4): 29-37. DOI: 10.18620/ctt-1866-8836-2018-7-429-37.

9. Shadrivova OV, Khostelidi SN, Chudinovskikh YA, Zabirov VS, Borzova YV, Desyatik EA, Volkova AG, Popova MO, Markova IV, Uspenskaya OS, Ruzhinskaya OS, Shneyder TV, Bogomolova TS, Ignatyeva SM, Zubarovskaya LS, Afanasyev BV, Klimko NN. Invasive aspergillosis and mucormycosis in oncohematological patients. Oncohematology 2018, 13(2):39-47. DOI: 10.17650/1818-8346-2018-13-2-3947. (In Russian).

10. Klimko NN, Khostelidi SN, Volkova AG, Popova MO, Bogomolova TS, Zubarovskaya LS, Kolbin AS, Medvedeva NV, Zuzgin IS, Simkin SM, Vasilyeva NV. Afanasyev BV. Mucormycosis in haematological patients: case report and results of prospective study in Saint Petersburg, Russia. Mycoses 2014, 57: 91-96. doi:10.1111/myc.12247.

11. Teng JC, Slavin MA, Teh BW, Lingaratnam SM, Ananda-Rajah MR, Worth LJ, Seymour JF, Thursky KA. Epidemiology of invasive fungal disease in lymphoproliferative dis- orders. Haematologica. 2015; 100(11):e462-6. doi: 10.3324/ haematol.2015.126698

12. Kontoyiannis DP, Marr KA, Park BJ, Alexander BD, Anaissie EJ, Walsh TJ, Ito J, Andes DR, Baddley JW, Brown JM, Brumble LM, Freifeld AG, Hadley S, Herwaldt LA, Kauffman CA, Knapp K, Lyon GM, Morrison VA, Papanicolaou G, Patterson TF, Perl TM, Schuster MG, Walker R, Wannemuehler KA, Wingard JR, Chiller TM, Pappas PG. Prospective surveillance for invasive fungal infections in hematopoietic stem cell transplant recipients, 2001-2006: overview of the transplant-associated infection surveillance network (TRANSNET) database. Clin Infect Dis. 2010, 50:1091-1100. DOI: 10.1086/651263.

13. Martino R, Lopez R, Sureda A, Brunet S, Domingo-Albos A. Risk of reactivation of a recent invasive fungal infection in patients with hematological malignancies undergoing further intensive chemo-radiotherapy. A single-center experience and review of the literature. Haematologica. 1997; 82:297-304.

14. Offner F, Cordonnier C, Ljungman P, Prentice HG, Engelhard D, De Bacquer D, Meunier F, De Pauw B. Impact of previous aspergillosis on the outcome of bone marrow transplantation. Clin Infect Dis. 1998, 26:1098-1103. DOI: $10.1086 / 520274$.

15. Marr KA, Carter RA, Crippa F, Wald A, Corey L. Epidemiology and outcome of mould infections in hematopoietic stem cell transplant recipients. Clin Infect Dis 2002;34: 909917. DOI: $10.1086 / 339202$.

16. Fukuda T, Boeckh M, Guthrie KA, Mattson DK, Owens S, Wald A, Sandmaier BM, Corey L, Storb RF, Marr KA. Invasive aspergillosis before allogeneic hematopoietic stem cell transplantation: 10-year experience at a single transplant center. Biol Blood Marrow Transplant. 2004; 10 : 494-503. DOI: 10.1016/j.bbmt.2004.02.006.

17. Maziarz RT, Brazauskas R, Chen M, McLeod AA, Martino R, Wingard JR, Aljurf M, Battiwalla M, Dvorak CC, Geroge B, Guinan EC, Hale GA, Lazarus HM, Lee JW, Liesveld JL, Ramanathan M, Reddy V, Savani BN, Smith FO, Strasfeld L, Taplitz RA, Ustun C, Boeckh MJ, Gea-Banacloche J, Lindemans CA, Auletta JJ, Riches ML. Pre-existing invasive fungal infection is not a contraindication for allogeneic HSCT for patients with hematologic malignancies: a CIBMTR study. Bone Marrow Transplant. 2017; 52(2):270-278. DOI: 10.1038/bmt.2016.259.

18. Popova MO, Volkova A, Elias Soulaiman S, Vavilov V, Bondarenko S, Slesarchuk O, Smirnova A, Shadrivova O, Khostelidi S, Ignatyeva S, Bogomolova T, Zubarovskaya L, Klimko N, Afanasyev B. Allogeneic hematopoietic stem cell transplantation in patients with invasive aspergillosis. Bone Marrow Transplantation. 2015, Volume 50, Supplement 1, S33.

19. Popova MO, Volkova AG, Soulaiman SE, Pinegina ON, Ignatyeva SM, Bogomolova T S, Smirnova AG, Vladovskaya M D, Bondarenko SN, Zubarovskaya LS, Klimko NN, Afanasyev BV. Outcome of allogeneic hematopoietic stem cell transplantation in patients with prior invasive aspergillosis. Blood. 2015; 126(23):3123; DOI: https://doi.org/ 
20. Penack O, Tridello G, Hoek J, Socié G, Blaise D, Passweg J, Chevallier P, Craddock C, Milpied N, Veelken H, Maertens J, Ljungman P, Cornelissen J, Thiebaut-Bertrand A, Lioure B, Michallet M, Iacobelli S, Nagler A, Mohty M, Cesaro S. Influence of pre-existing invasive aspergillosis on allo-HSCT outcome: a retrospective EBMT analysis by the Infectious Diseases and Acute Leukemia Working Parties. Bone Marrow Transplant. 2016; 51(3):418-23. doi: 10.1038/ bmt.2015.237.

21. Allinson K, Kolve H, Gumbinger HG, Vormoor HJ, Ehlert K, Groll AH. Secondary antifungal prophylaxis in paediatric allogeneic haematopoietic stem cell recipients. J Antimicrob Chemother. 2008;61:734-742.

22. Cordonnier C, Maury S, Pautas C, Bastie JN, Chehata S, Castaigne S, Kuentz M, Bretagne S, Ribaud P. Secondary antifungal prophylaxis with voriconazole to adhere to scheduled treatment in leukemic patients and stem cell transplant recipients. Bone Marrow Transplant. 2004;33(9):943-948.

23. Cordonnier C, Rovira M, Maertens J, Olavarria E, Faucher C, Bilger K, Pigneux A, Cornely OA, Ullmann AJ, Bofarull RM, de la Cámara R, Weisser M, Liakopoulou E, Abecasis M, Heussel CP, Pineau M, Ljungman P, Einsele H. Voriconazole for secondary prophylaxis of invasive fungal infections in patients with allogeneic stem cell transplants recipients: results of the VOSIFI Study Group; Infectious Diseases Working Party, European Group for Blood and Marrow Transplantation. Haematologica. 2010; 95(10):17621768. doi: 10.3324/haematol.2009.020073.

24. Azoulay E, Mokart D, Pène F, Lambert J, Kouatchet A, Mayaux J, Vincent F, Nyunga M, Bruneel F, Laisne LM, Rabbat A, Lebert C, Perez P, Chaize M, Renault A, Meert AP, Benoit D, Hamidfar R, Jourdain M, Darmon M, Schlemmer B, Chevret S, Lemiale V. Outcomes of critically ill patients with hematologic malignancies: prospective multicenter data from France and Belgium - a groupe de recherche respiratoire en reanimation onco-hematologique study. J Clin Oncol. 2013;31(22):2810-2818. doi: 10.1200/JCO.2012.47.2365.

25. Legrand M, Max A, Peigne V, Mariotte E, Canet E, Debrumetz A, Lemiale V, Seguin A, Darmon M, Schlemmer B, Azoulay E. Survival in neutropenic patients with severe sepsis or septic shock. Crit Care Med. 2012;40(1):43-9. doi: 10.1097/CCM.0b013e31822b50c2.

\title{
| Аллогенная трансплантация гемопоэтических стволовых клеток у детей и взрослых с предшеству- ющими трансплантации инвазивными микозами
}

\author{
Марина О. Попова $^{1}$, Алиса Г. Волкова ${ }^{1}$, Инна В. Маркова ${ }^{1}$, Оксана В. Айзсилниекс ${ }^{1}$, Юлия А. Рогачева ${ }^{1}$, \\ Анастасия С. Фролова ${ }^{1}$, Александр Н. Швецов ${ }^{1}$, Илья Ю. Николаев ${ }^{1}$, Светлана М. Игнатьева ${ }^{2}$, \\ Татьяна С. Богомолова ${ }^{2}$, Асмик Г. Геворгян ${ }^{1}$, Олеся В. Паина ${ }^{1}$, Татьяна А. Быкова ${ }^{1}$, Елена И. Дарская ${ }^{1}$, \\ Мария В. Владовская ${ }^{1}$, Иван С. Моисеев ${ }^{1}$, Людмила С. Зубаровская ${ }^{1}$, Николай Н. Климко ${ }^{1,2}$, Борис В. Афанасьев ${ }^{1}$ \\ ${ }^{1}$ НИИ детской онкологии, гематологии и трансплантологии им. Р. М. Горбачевой, Первый Санкт-Петербургсий \\ государственный медицинский университет им. акад. И. П. Павлова, Санкт-Петербург, Россия \\ ${ }^{2}$ НИИ Медицинской микологии им. П. Н. Кашкина, Северо-западный государственный медицинский университет \\ им. И. И. Мечникова, Санкт-Петербург, Россия
}

\section{Резюме}

Внедрение новых противогрибковых средств и диагностических процедур улучшило прогноз гематологических пациентов с инвазивными микозами (ИМ). Увеличилось число пациентов с ИМ, кандидатов на аллогенную трансплантацию гемопоэтических стволовых клеток (алло-ТГСК). Роль ИМ, развившихся до алло-ТГСК, по-прежнему не определена. Нет опубликованных данных о результатах алло-ТГСК у педиатрических пациентов с предшествующим ИМ. Цель исследования - оценить влияние предшествующего ИМ на результаты аллоТГСК.

\section{Пациенты и методы}

В проспективное исследование были включены 504 реципиента алло-ТГСК в период с января 2013 года по июль 2016 года. Средний возраст составил 24 года (2 месяца - 76 лет), дети (<18 лет) - 164, взрослые 340 , мужчины - 52\%. Преимущественно пациенты с диагнозом острый лейкоз группы высокого риска (74,6\%). Алло-ТГСК от неродственного совместимого донора были выполнены у 58,5\%, совместимого родственного донора - 22,5\%, гаплоидентичного $19 \%$, преимущественно с использованием режима кондиционирования со сниженной интенсивностью (67\%). Непосредственно перед алло-ТГСК всем 
пациентам с обнаруженными изменениями ткани легких, в результате компьютерной томографии органов грудной клетки, выполнялась бронхоскопия с исследованием жидкости бронхоальвеолярного лаважа: микроскопии, культуры и теста на галактоманнан. Для диагностики доказанного и вероятного ИМ и оценки ответа на терапию были использованы критерии EORTC/MSG 2008. «Активный ИМ»ИМ, диагностированный непосредственно перед трансплантацией. Медиана наблюдения составила 20 месяцев. Основными конечными точками были общая выживаемость (OB), частота рецидива или прогрессирования ИМ после алло-ТГСК; вторичные точки - частота острой и хронической РТПХ, рецидива основного заболевания.

\section{Результаты}

Частота ИМ до алло-ТГСК составила 15\% (n=76). Согласно критериям EORTS/MSG 2008, 90,8\% пациентов имели вероятный и 9,2\% доказанный ИМ. Этиология ИМ до трансплантации: инвазивный аспергиллез (ИА) - 75\%, инвазивный кандидоз (ИК) - 13\%, мукормикоз (М) - 4\%, пневмоцистная пневмония (ПП) - 1,3\% и комбинация ИА с М диагностирована у 2 пациентов, с ИК - 1, с ПП - 1 . Основным органом поражения были легкие - 95\%, другие локализации, преимущественно в сочетании с вовлечением легких: синусы - 9\%, селезенка - 6\%, печень - 6\%, и мягкие ткани - 3\%. Противогрибковая терапия перед алло-ТГСК применялась у 75\% пациентов с медианой продолжительности - 2 месяца. Полный ответ на противогрибковую терапию был достигнут у $38,2 \%$ пациентов, частичный ответ или стабилизация - 35,5\%, а у $26,3 \%$ пациентов был «активный ИМ». После алло-ТГСК все пациенты получали противогрибковую терапию или вторичную профилактику в соответствии с этиологией ИМ. Кумулятивная частота рецидива или прогрессирования ИМ после алло-ТГСК составила $14,5 \%$. Отсутствие ремиссии основного заболевания в момент трансплантации был единственным фактором риска рецидива или прогрессирования ИМ после
алло-ТГСК (11,5\% против 21,1\%, p=0,03). Существенных различий в кумулятивной частоте острой $(\mathrm{p}=0,28)$, хронической РТПХ $(\mathrm{p}=0,25)$ и рецидива $(\mathrm{p}=0,31)$ не было обнаружено в сравнении с группой пациентов без ИМ в анамнезе. 3-летняя ОВ после алло-ТГСК составила $67,5 \%$. Общая выживаемость у реципиентов аллоТГСК без ИМ и имевших ИМ в анамнезе статистически не различалась во всех группах (60,5\% против 68,7\%, p=0,1), как отдельно у детей (50,0\% против 57,4\%, P=0,32) так и у взрослых (63,3\% против 74,6\%, p=0,09). Наихудший результат наблюдался у пациентов с «активным ИМ» и отсутствием ремиссии основного заболевания на момент трансплантации (3-летняя ОВ - 20\%, p <0,001). Однако у пациентов с «активным ИМ» и ремиссией основного заболевания ОВ была аналогична выживаемости пациентов без ИМ в ананмнезе (80\% против $68,7 \%, \mathrm{p}=0,57)$.

\section{Выводы}

Пятнадцать процентов реципиентов алло-ТГСК имели инвазивный микоз в анамнезе. Кумулятивная частота рецидива или прогрессирования инвазивных микозов после алло-ТГСК составила 14,5\%. Предшествующий инвазивный микоз не оказывал существенного влияния на результаты трансплантации и общую выживаемость детей и взрослых после алло-ТГСК. Отсутствие ремиссии основного заболевания на момент трансплантации было единственным фактором риска рецидива или прогрессирования инвазивного микоза, и ухудшения результатов алло-ТГСК.

\section{Ключевые слова}

Предшествующие инвазивные микозы, аллогенная трансплантация гемопоэтических стволовых клеток, дети и взрослые, клинические исходы. 